\title{
Assessing the causes of conflict and its effect on livelihoods: a study from Bardia National Park and Khata Corridor, Nepal.
}

\begin{abstract}
S.C. Nepali $^{1}$
The ten-year conflict in Nepal can be viewed as the result of ignoring and failing to strengthen the state and nation building through political, economic and social integration. This study aimed to understand and assess the causes of conflict and their effects on livelihoods in and around Bardia National Park, Nepal. Crotty's model has been used to collect the information and conduct non parametric Wilcoxon test. Chi-square test with descriptive tables has been used for data analysis. Causes of conflict based on people's perception revealed that $78 \%$ and $45 \%$ of the respondents agreed that weak governance was the cause of conflict before and after. $79 \%$ and $52 \%$ attributed economical instability as a cause while $78 \%$ and $49 \%$ believed disparity in resource use and distribution as the cause of conflict before and after. The overall impact on livelihoods due to the conflict had a weighted mean range 2.0-2.3, suggesting the medium impact on all the assets. The conditions of livelihood were better before and were negatively affected after the conflict. Studying patterns of armed conflict and their impact in a country like Nepal is not just of historical interest, but also a matter of current concern for development.
\end{abstract}

Key words: Conflict, instability livelihoods, non parametric test

C onflict has been defined in various terms based on a range of categories, from serious disagreement to violence leading towards war and change in the society (Homer-Dixon, 1991 and Warner and Jones, 1998). In addition to the war with English East India Company in 1814, Nepal witnessed ten years of "people's war" between the Maoists and the State during 1996-2006. This war not only claimed the lives of thousands of people, but it also had a severe impact on conservation and livelihoods. Though Nepal was united into one country from several principalities, the autocratic rulers failed from the beginning to strengthen the state formation process; nation building through political, economic and social integration was completely ignored. Collier and Hoefler, (1998), Arnson et al., (2005), Jung (2003), Upreti, (2004), Upreti, (2007) ascribed the causes of conflict to poor socio-economic factors, differences in ideology, identity, geographical causes, international causes, environmental causes, poor governance, poverty and exclusion and inequalities. Maybe a combination of these factors has triggered the conflict in Nepal. The relationship of war and environment have been documented by Homer-Dixon (1991), Homer and Dixon (1994), Collier and Hoeffler (2004).

\section{Materials and methods}

Choosing a research approach within the natural and social sciences in a society influenced by post structural and post modern discourse is a different task today than it was in the past. Research methodology framework adopted for this study was based on Crotty's (1998) model. This research has employed an interdisciplinary approach to be understood in terms of a process rather than a representation. As the study tried to look into the relation of natural and social science, research here involved the collection of empirical data from the field and extending the discussion to include those who are the foci of this study. This study, therefore, aims to understand and assess the causes of conflict and their effects on the livelihoods in and around Bardia National Park and Khata Corridor.

Ph.D student, Institute of Forestry, Tribhuvan University, Nepal. E-mail: sushila_nepali@yahoo.com 
Chart 1- Research Methodology Framework

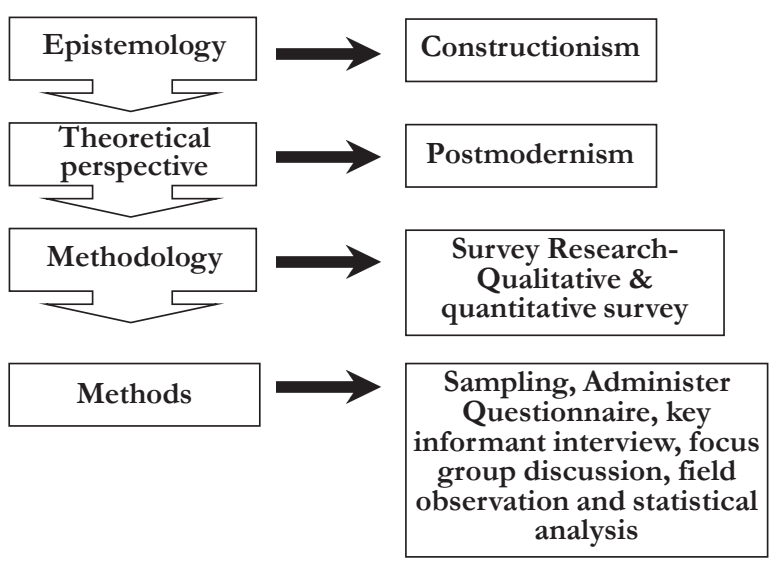

Source: adopted by Crotty, 1998.

\section{Data Collection}

The collection of the data for the survey was based on multistage sampling technique. Preliminary field visit and collection of secondary data from the park and projects working in the area was conducted. The data was collected from 10 VDCs of Bagnaha, Neulapur, Magaragadhi/Baniyabhar, Thakurdwara, Suryapatuwa, Shivpur, Dhodhari, Gola and Manau. $10 \%$ of the households from each VDC were randomly selected for detailed questionnaire survey.

\section{Data Processing and Analysis}

As Zar (1996) explains, there is a large body of statistical methods that comprises procedures not requiring the estimation of the population variance or mean and not stating hypotheses about parameters. These testing procedures are termed as nonparametric tests or distribution free test. Data collected were processed and analyzed using SPSS/PC computer software. For testing the results that were mainly categorical, various non-parametric tests such as Wilcoxon sign rank test2 and descriptive analysis with graphical representation have been applied for the analysis to measure significance Zar, (1996); Siegel et al., (1988). Wilcoxon signed-rank test is applied to compute the differences between the two variables for all cases and classifies the differences as positive, negative or tied. Then summation with the ranks having plus sign $\left(T_{+}\right)$and the ranks with minus sign $(\mathrm{T})$ is done. For two-tailed test, $\mathrm{Ho}_{\mathrm{o}}$ is rejected if either $\mathrm{T}_{+}$or $\mathrm{T}_{-}$is less than or equal to the critical value, $T_{ \pm(2), \mathrm{n}}$, from the given table.

Having calculated either $\mathrm{T}+$ or $\mathrm{T}-$, the other can be determined as $\mathrm{T}-\mathrm{n}(\mathrm{n}+1) / 2=\mathrm{T}+\mathrm{P}$-value calculated is the probability of being wrong in concluding that there is a true effect (i.e., the probability of falsely rejecting the null hypothesis, or committing a Type I error, based on $\mathrm{W})$. The smaller the $\mathrm{p}$-value, the greater the probability that there is a treatment effect. Traditionally, it can be concluded that there is a significant difference when $\mathrm{p}<0.05$.

Five point Likert Scale3 (Likert, 1974) point ranking was used to analyze people's perceptions of conflict and its impact in conservation and livelihoods. The perceptions of user in terms of changes in the communities during the conflict times: conflict before (1996-2000) and after (2001-2006) were recorded in five ordinal scales including "Strongly agreeing/very high", "Agreeing/high", "Disagree/medium/don't know", "Strongly disagree/low" and "Very low/no change". To measure the strengths or effects of the impact, classification was done as follows: very high degree impact meant $>80 \%$, high degree is $60-80 \%$, medium degree is $40-60 \%$, low degree meant $20-40 \%$ and very low degree as $<20 \%$.

\section{Results and Discussion}

\section{Perception on causes of conflict}

Total of 1118 individuals from the aforementioned 10 VDCs were invited to agree or disagree with the given statements based on the Likert scale. Statements used for analyzing the causes of conflict have been updated based on Upreti (2004), Upreti (2007) and Sambaugh et al., (2001). Causes of conflict have been classified into broader reasons and specific reasons as given in Box 1.

Box 1, lists weak governance, economic instability and weak resource use and distribution as the broader reasons and these were further classified into specific reasons. The following result analyzes each broader category with specific reasons.

\section{Weak governance perceived as a cause of conflict:}

Majority of the respondents (78\%) 'agreed' and 'strongly agreed' that conflict occurred because of weak governance (Figure 1). In total, 17\% and 5\% of the respondents 'did not know' and 'strongly disagreed' with the statement that weak governance was the reason for causing the conflict, respectively, before. Comparing the same statement after the

\footnotetext{
2 Frank Wilcoxon (1892-1965), American (though born in Ireland) chemist and statistician, a major developer of statistical methods based on ranks
} 
Box 1: Causes of conflict broader and specific reasons

\begin{tabular}{|c|c|c|}
\hline Broad Reason & Code & Specific reason \\
\hline \multirow{6}{*}{$\begin{array}{l}\text { Weak } \\
\text { Governance }\end{array}$} & $\mathrm{C} 1$ & The government was lacking accountability, responsiveness and transparency \\
\hline & $\mathrm{C} 2$ & Lacking in functioning regulatory/legal framework \\
\hline & $\mathrm{C} 3$ & Inadequate independent and neutral judiciary or other forms of redress of grievances \\
\hline & $\mathrm{C} 4$ & $\begin{array}{l}\text { There are disputes among central, regional and local governments over the use of } \\
\text { revenue }\end{array}$ \\
\hline & C5 & $\begin{array}{l}\text { Lack of community consultation in project planning can lead to community confusion, } \\
\text { opposition \& violence }\end{array}$ \\
\hline & C6 & $\begin{array}{l}\text { Lack of social inclusion in equal participation for management and decision making } \\
\text { activities }\end{array}$ \\
\hline \multirow{3}{*}{$\begin{array}{l}\text { Economic } \\
\text { instability }\end{array}$} & $\mathrm{C} 7$ & Increase in corruption \\
\hline & $\mathrm{C} 8$ & Government providing inadequate basic services and not prioritizing \\
\hline & C9 & Inequalities in wealth distribution \\
\hline \multirow{3}{*}{$\begin{array}{c}\text { Resource Use } \\
\text { and } \\
\text { Distribution }\end{array}$} & C10 & Competing claims to land rights \& natural resources \\
\hline & C11 & Lack of education in resource management and distribution \\
\hline & C12 & Degrading environment having negative affect on livelihoods \\
\hline
\end{tabular}

Source: updated from Upreti, 2004 and Shambaugh, et al. 2001.

conflict revealed that only $51 \%$ of the respondents thought that weak governance was the cause of conflict, but $40 \%$ of them 'did not know' if this was the cause.

Analyzing the individual or specific reasons, Figure 1 suggests that out of various specific reasons, $89 \%$ of the respondents 'agree/strongly agreed' that the government was lacking responsibility, accountability and transparency. When comparing after the conflict or during, $55 \%$ and $56 \%$ of the respondents agreed that inadequate forms of redressing grievances and disputes over revenue sharing were the causes of conflict.

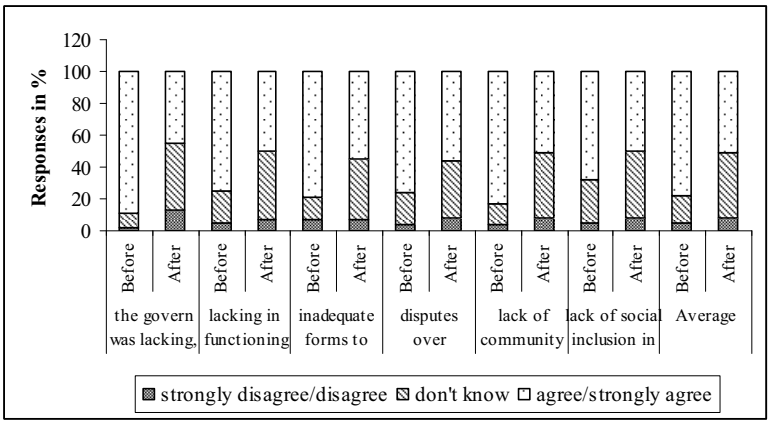

Source: Field data 2006, Bardia

Fig 1 : Weak governance as a cause of conflict

The results also underscore that $68 \%$ of the respondents 'agreed/strongly agreed'; however, the smallest portion attributed the lack of social inclusion in equal participation before as the cause of conflict. But after the conflict, the least portion (45\%) agreed with the statement that the government did not have or lacked responsibility, accountability and transparency. The power struggle related to the fight for their identity and lack of development in the country was very prominent. One of the root causes of Nepal's slow development is "institutional problems", a euphemism that covers a multitude of sins. They also strongly agreed that there was not a functioning regulatory or legal framework to tackle the issues of governance. The studies conducted by World Bank Institute Governance Index for Nepal (1996-2006) also reported that the governing situation had witnessed a declining trend when compared with the South Asia Region as a whole (Narayan Manandhar, the Kathmandu Post 19 July 2007, cited by Upreti 2007).

Over the years since 1990, governments had made promises to the people and distributed hopes and "dreams" of an improved quality of life. The misuse of funds, power results in wealth that is concentrated around the capital where most of the development stays. This situation can build the perception of the people who strongly agree that resource and revenues were not utilized properly. The results above revealed that the majority of the respondents agreed that lack of social inclusion was a cause of conflict. There is no doubt that existing literatures within the country and across region have confirmed that gender, social equity/inclusion and poverty considerations are still weak.

\footnotetext{
3 Likert scaling is widely used format developed by Rensis Likert for asking attitude questions. Respondents are typically asked their degree of agreement with a series of statements that together form a multiple indicator or item measure.
} 


\section{Economic instability as cause of conflict:}

Figure 2 suggests that $79 \%$ and $52 \%$ of the respondents 'strongly agreed' that economic instability was the cause of conflict both before and after the conflict whereas $7 \%$ and $14 \%$ 'disagreed' and 'did not know' the cause before and $8 \%$ and $40 \%$ of the respondents 'disagreed' and 'did not know' after.

There are three specific reasons within economic instability; and among them, $89 \%$ and $56 \%$ of the respondents 'strongly agreed' that increase in corruption within the system had led to conflict before and after, respectively. Out of these three reasons, $73 \%$ of the respondents 'strongly agreed' with the saying that causes of conflict occurred because the government was not providing sufficient basic services. However, after the conflict, the least agreed, $49 \%$ of the respondents, 'agreed' that inequalities in wealth distribution were the cause of economic instability.

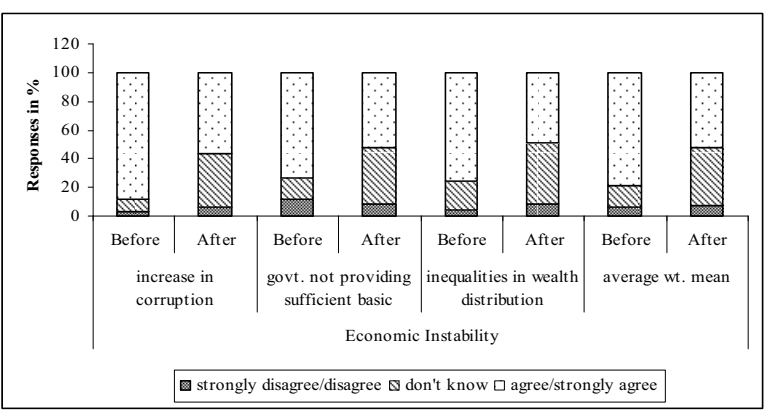

Source: Field data 2006, Bardia

Fig 2: Economic Instability as a cause of conflict

Nepal as a country moving towards modernization has been making efforts to address the economic situation but got bogged down in the absence of the political space necessary for a system of performance based upward mobility while corruption is on the rise (Thapa and Sijapati, 2003). Nepal's gravest institutional problem is corruption, which seems to plumb new depths with each short-lived government (Khanal, 2006). The Neoclassical theory of greed (instead of focusing on grievances or developing economic agendas) by the previous rulers of Nepal can be confirmed by the argument made by Collier and Hoeffler (2004).

Once Nepal was known to the greater world, development in industries and health sectors became started, but this was mostly done in the top-down approach, instead of identifying or addressing people's needs. In a series of studies, Blaikie, et al., (1980) have extensively documented what they call 'Nepal in Crisis' and focussed on the economic inequality driving conflicts. It has been indicated and stressed that there has been an increase in inequality between socio-economic groups, leading to further exclusion of already marginalized groups, and this helped explain the expansion of civil conflict in Nepal. It is important to focus on the variety of ways by which inequalities are managed by societies and the significance of varying kinds of inequality (Cramer, 2003; Robinson, 2001).

\section{Unequal resource use and distribution as a cause of conflict:}

Figure 3 suggests that resource use and distribution as cause of conflict was 'strongly agreed' by $78 \%$ of the respondents before and $49 \%$ after the conflict. $6 \%$ and $16 \%$ of the respondents 'disagreed' and 'did not know' that resource use and distribution were the causes of conflict before, but $9 \%$ and $42 \%$ of the respondents happened to 'disagree' and 'did not know' after the conflict. $85 \%$ of the respondents may have 'strongly agreed' with a specific reason such as inadequate education in resource use and distribution before, but $56 \%$ of the respondents mentioned degradation of the environment having an impact upon resource use and distribution causing conflict after. Before the conflict, $74 \%$ of the respondents had 'strongly agreed' that competing claims on land and natural resources and degradation of the environment caused conflict. But after the conflict, $42 \%$ of the respondents thought competing claims on land and natural resources as the cause of conflict. The responses shown here definitely indicate that the understanding of the cause of conflict differs with the ethnicity, status, age group, literacy, employment, land holding and income of the respondents.

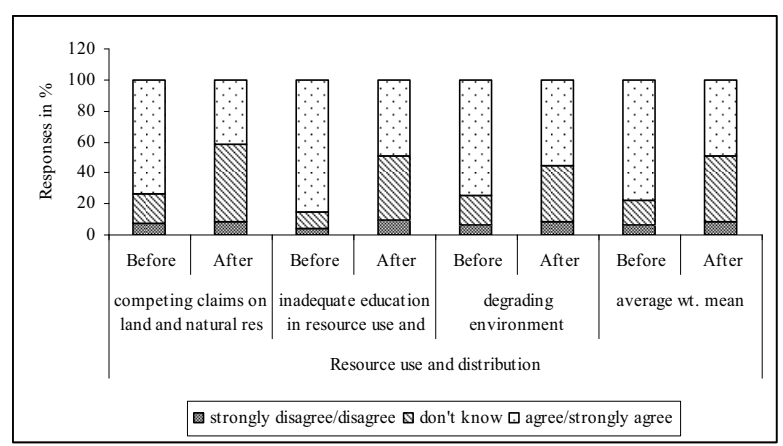

Source: Field data 2006, Bardia

Fig 3: Unequal resource use and distribution as a cause of conflict 
Studies of violent conflicts do show that they begin with the political economy and the mechanisms of access, control, and struggle over resources. Studies carried out in Nepal regarding resource use conflict and leading to park-people conflict or conflict with forest officers have been documented by Upreti, 2007. These findings revealed that, on average, $74 \%$ agreeing with the statements reasoning the facts that there were competing claims to land rights \& natural resources; environmental degradation in the area had affected the traditional livelihood of the community; there were projects which had not felt responsible to tackle environment problems and encourage people to participate; people had perceived the importance of natural resources and their impact on livelihoods; they had also seen the negative effects due to unmanaged natural resources on their livelihoods and that this has impacted social and cultural trends.

The influence of society, state, corporate and various powers has an impact on degrading the environment or influencing environmental policies. The inter relation between power groups monopolizing policy, legitimizing their power to seize common resources can be understood through "Political ecology" theory. Upreti, 2007, has cited various studies, most of which have stressed the relationship between armed conflict and natural resources. The government and community forestry areas have been misused for their camps. Upreti, (2004); Blaikie et al., (1980), have addressed that structural global political economy approach to explain social marginalization and environmental degradation. Civil war can limit the access to resources and only few groups or people will have access and power to use them for their own benefit. The study by Le Billon (2000) documents how armed groups can gain economically and exploit natural resources. In the case of Nepal, it may be difficult to document what and how much natural resources were diminished.

\section{Determining the associated factors with causes of conflict and its perceived effect on livelihoods}

This section analyses the factors associated with the causes of conflict and their relation to livelihoods. Table 2 shows that understanding among the respondents differed in agreeing about the causes before and after the conflict. In the case of weak

Table 2 : Summary table showing the significance and linear combination of the independent variables to the causes of conflict

\begin{tabular}{|c|c|c|c|c|c|c|c|c|c|}
\hline $\begin{array}{l}\text { Broader } \\
\text { reasons }\end{array}$ & $\begin{array}{c}\text { causes of } \\
\text { conflict }\end{array}$ & Periods & $\begin{array}{l}\text { wt. } \\
\text { mean }\end{array}$ & difference & W & $\mathbf{T}+$ & T- & P-value & $\begin{array}{c}\text { Changes } \\
\text { impact }\end{array}$ \\
\hline \multirow{12}{*}{ 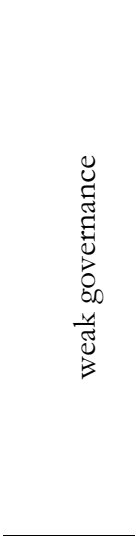 } & \multirow{2}{*}{ C1 } & Before & 2.9 & \multirow{2}{*}{0.58} & \multirow{2}{*}{-144033.00} & \multirow{2}{*}{210.00} & \multirow{2}{*}{-144243.00} & \multirow{2}{*}{$<0.001$} & \multirow{2}{*}{$b>$ or +} \\
\hline & & After & 2.3 & & & & & & \\
\hline & \multirow[t]{2}{*}{ C2 } & Before & 2.7 & \multirow[t]{2}{*}{0.31} & \multirow[t]{2}{*}{-88028.00} & \multirow[t]{2}{*}{38786.00} & \multirow[t]{2}{*}{-126814.00} & \multirow[t]{2}{*}{$<0.001$} & \multirow[t]{2}{*}{$b>$ or +} \\
\hline & & After & 2.4 & & & & & & \\
\hline & \multirow{2}{*}{ C3 } & Before & 2.7 & \multirow{2}{*}{0.26} & \multirow{2}{*}{-66872.00} & \multirow{2}{*}{44824.00} & \multirow{2}{*}{-111696.00} & \multirow{2}{*}{$<0.001$} & \multirow{2}{*}{$b>$ or +} \\
\hline & & After & 2.5 & & & & & & \\
\hline & \multirow{2}{*}{$\mathrm{C} 4$} & Before & 2.7 & \multirow{2}{*}{-0.16} & \multirow[t]{2}{*}{48607.00} & \multirow[t]{2}{*}{105101.50} & \multirow{2}{*}{-56494.50} & \multirow[t]{2}{*}{$<0.001$} & \multirow[t]{2}{*}{$\mathrm{b}<$ or -} \\
\hline & & After & 2.9 & & & & & & \\
\hline & \multirow{2}{*}{ C5 } & Before & 2.8 & \multirow{2}{*}{0.47} & \multirow{2}{*}{-143556.00} & 26975.00 & -170531.00 & $<0.001$ & $\mathrm{~b}>$ or + \\
\hline & & After & 2.3 & & & & & & \\
\hline & $C 6$ & Before & 2.6 & 031 & -10073700 & 52833.00 & -153570.00 & $<0.001$ & $b>$ or \\
\hline & 60 & After & 2.3 & 0.31 & & & & & $\mathrm{D}=$ or \\
\hline : & C7 & Before & 2.9 & 0.36 & -7902800 & 1489150 & -93919 50 & $<0.001$ & $\mathrm{~b}>$ or + \\
\hline है & & After & 2.5 & & & & & & \\
\hline.$\leftrightarrows$ & C8 & Before & 2.6 & 0.17 & -42749.00 & 65208.50 & -107957.50 & $<0.001$ & $b>$ or + \\
\hline $\mathscr{\Xi}$ & & After & 2.4 & & & & & & \\
\hline : & C9 & Before & 2.7 & 0.30 & -83065.00 & 41844.00 & -124909.00 & $<0.001$ & $\mathrm{~b}>$ or + \\
\hline U & & After & 2.4 & & & & & & \\
\hline & C10 & Before & 2.7 & 0.33 & -97296.00 & 44835.00 & -142131.00 & $<0.001$ & $>$ or + \\
\hline$\underset{0}{\tilde{\pi}}$ & & After & 2.3 & & & & & & \\
\hline 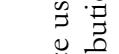 & C11 & Before & 2.8 & 0.40 & -110302.00 & 29094.00 & -139396.00 & $<0.001$ & $b>$ or + \\
\hline$\stackrel{\breve{g}}{\vec{E}}$ & C11 & After & 2.4 & 0.40 & $-11050<.00$ & & & & \\
\hline 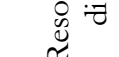 & C12 & Before & 2.7 & 0.21 & -55303.00 & 52579.00 & -107882.00 & $<0.001$ & $b>$ or + \\
\hline & & After & 2.5 & & & & & & \\
\hline
\end{tabular}

Source: Field Data, Bardia, 2006 
governance becoming the cause of conflict, most of the respondents agreed the causes to be greater before than after the conflict except for the cause where respondents agreed that disputes over revenue sharing got worse than before. Thus, it is significantly different with p-values $<0.001$ and signifies that after the conflict, respondents' perception of conflict and its causes changed showing positive impact.

With respect to economic instability, resource use and distribution, all respondents agreed that the causes of conflict were greater before than after. The respondents perceived some changes after and identified different causes of conflict than before.

\section{Analyzing the conditions of livelihoods before and after the conflict}

After analyzing all the causes of conflict and their impacts on livelihood assets, the conditions of livelihood assets based on their perception before and after the conflict were queried. Table 3 demonstrates that $83 \%$ of the respondents recalled that social assets were good before and 65\% mentioned that they got bad after the conflict intensified. In the case of financial assets, $87 \%$ of the respondents perceived the condition as good before and $66 \%$ of them felt it was bad after. Similarly, physical assets were perceived to be good by $77 \%$ of the respondents before but bad by $68 \%$ of the respondents. $85 \%$ of the respondents reckoned natural assets to be good before the conflict and $71 \%$ of the respondents saw them to be bad after. Finally, human resource assets were perceived to be good by $81 \%$ before, and $67 \%$ mentioned it be bad after the conflict.

All livelihood issues deal with communities being poor, deprived and their well being attached to various assets and access to resources and services. As Rakodi and Lloud-Johnson (2002) put it, livelihood approaches propose to think in terms of strengths or assets, or who has access to what in terms of savings; if not, have other materials or non material assets distinguishing between poor, deprived or the better off. As the livelihood framework addresses human links to various assets such as social, financial, natural, human and physical, when these assets become vulnerable, livelihoods deteriorate. Therefore, when the country is in crisis the first impact is seen on these livelihood assets.

\section{Conclusion}

Weak governance, economic instability and inequality in resource use and distribution as the perceived causes of conflict before and after persisted and were highly significant. The 10-year long conflict made the country's economic, political and social situation very miserable and this is revealed in impacts on livelihoods which were perceived as better before and worse after the conflict. This study could be a lesson for learning how to cope with such situation in future by addressing the livelihood options

Table 3 : Conditions of livelihood assets before and after or during the conflict

\begin{tabular}{|c|c|c|c|c|c|c|c|c|c|c|c|c|c|c|c|c|c|c|c|c|}
\hline \multirow{3}{*}{ Condition } & \multicolumn{4}{|c|}{ social } & \multicolumn{4}{|c|}{ financial } & \multicolumn{4}{|c|}{ physical } & \multicolumn{4}{|c|}{ natural asset } & \multicolumn{4}{|c|}{ human res asset } \\
\hline & \multicolumn{2}{|c|}{ before } & \multicolumn{2}{|c|}{ after } & \multicolumn{2}{|c|}{ Before } & \multicolumn{2}{|c|}{ after } & \multicolumn{2}{|c|}{ before } & \multicolumn{2}{|c|}{ after } & \multicolumn{2}{|c|}{ before } & \multicolumn{2}{|c|}{ after } & \multicolumn{2}{|c|}{ before } & \multicolumn{2}{|c|}{ after } \\
\hline & Freq. & $\%$ & Freq. & $\%$ & Freq. & $\%$ & Freq. & $\%$ & Freq. & $\%$ & Freq. & $\%$ & Freq. & $\%$ & Freq. & $\%$ & Freq. & $\%$ & Freq. & $\%$ \\
\hline $\mathrm{Bad}$ & 12 & 1 & 723 & 65 & 14 & 1 & 737 & 66 & 17 & 2 & 765 & 68 & 12 & 1 & 789 & 71 & 17 & 2 & 748 & 67 \\
\hline Same & 174 & 16 & 151 & 14 & 130 & 12 & 173 & 15 & 243 & 22 & 163 & 15 & 155 & 14 & 103 & 9 & 196 & 18 & 185 & 17 \\
\hline Good & 932 & 83 & 244 & 22 & 974 & 87 & 208 & 19 & 858 & 77 & 190 & 17 & 951 & 85 & 226 & 20 & 905 & 81 & 185 & 17 \\
\hline
\end{tabular}

Source: Field Data, Bardia, 2006 


\section{References}

Arnson, C.J and Zartman, I.W. 2005. Rethinking the Economics of War-The Intersection of Need, Creed and Greed. Woodrow Wilson Center Press. Washington D.C and The John Hopkins University Press, Baltimore.

Blaikie, P.M., Cameron, J. and Seddon, D. 1980. Nepal in Crisis: Growth and Stagnation at the Periphery. Oxford, UK: Oxford University Press.

Collier, P. and Hoeffler, A. 1998. On the economic consequences of civil war. Oxford Economic Papers 50: 563-573.

Collier, P. and Hoeffler, A. 2004. Greed and grievance in civil war. Oxford Economic paper 56: 563-595.

Cramer, C., 2003. Does inequality cause conflict? Journal of International Development 15: 397-412.

Crotty, M. 1998. The Foundations of Social Research. Meaning and Perspective in the Research Process. Australia.

Homer-Dixon, T.F. 1991. On the threshold: environmental changes as causes of acute conflict. International Security, 16 (2): 76-116.

Homer-Dixon, T.F. 1994. Environmental Scarcities and Violent Conflicts: Evidence from Cases, International security, 19 (19): 5-40.

Jung, D. 2003. Shadow Globalization, Ethnic Conflicts and New Wars. A Political Economy of Intra-State War. Routledge Taylor and Francis Group, London and New York.

Khanal, D.R. 2006. Sasastra Dwandama Samudayik Ban (Community Forestry in Armed Conflict), Kathmandu: Federation of Community Forestry Users of Nepal.
Le Billon, P. 2000. The political ecology of transition in Cambodia, 1989-1999: war, peace and forest exploitation. Development and Change, 31 (4): 785805.

Rakodi, C. and Johnson, T. 2002. Urban Livelihoods: A People-Centered Approach to Reducing Poverty. Sterling, VA: Earthscan.

Robinson, 2001. Social identity, inequality and conflict. Journal of Economics of Governance 2: 8599.

Siegel, S and Castellan. Jr., N.J. 1988 Nonparametric Statistics for the Behavioral Sciences. McGraw-hill book company, Singapore.

Shambaugh, J. Oglethorpe, J. and Ham, R. (with contributions from Sylvia Tognetti) 2001. The Trampled Grass: Mitigating the Impacts of Armed Conflict on the Environment. Washington DC, USA: Biodiversity Support Program.

Thapa, D. and Sijapati, B. 2003. A Kingdom under Siege: Nepal's Maoist Insurgency, 1996 to 2003. Kathmandu: Printhouse.

Upreti, B.R. 2004. The Price of Neglect: From Resource Conflict to Maoist Insurgency in the Himalayan Kingdom. Bhrikuti Academic Publication. Kathmandu.

Upreti, B.R. 2007. Crisis beyond the Battlefield: A Rapid Impact Assessment of the Armed Conflict on Environment and Biodiversity in Nepal. Unpublished. Kathmandu.

Zar, J.H. 1996. Biostatistical Analysis, Third Edition, Prentice Hall, Upper Saddle River, New Jersey 07458. 